\title{
National Culture and Bank Risk-Taking
}

DOI:

10.1016/j.jfs.2017.08.007

\section{Document Version}

Accepted author manuscript

Link to publication record in Manchester Research Explorer

\section{Citation for published version (APA):}

Mourouzidou Damtsa, S., Milidonis, A., \& Stathopoulos, K. (2019). National Culture and Bank Risk-Taking. Journal of Financial Stability, 40(1), 132-143. https://doi.org/10.1016/j.jfs.2017.08.007

\section{Published in:}

Journal of Financial Stability

\section{Citing this paper}

Please note that where the full-text provided on Manchester Research Explorer is the Author Accepted Manuscript or Proof version this may differ from the final Published version. If citing, it is advised that you check and use the publisher's definitive version.

\section{General rights}

Copyright and moral rights for the publications made accessible in the Research Explorer are retained by the authors and/or other copyright owners and it is a condition of accessing publications that users recognise and abide by the legal requirements associated with these rights.

\section{Takedown policy}

If you believe that this document breaches copyright please refer to the University of Manchester's Takedown Procedures [http://man.ac.uk/04Y6Bo] or contact uml.scholarlycommunications@manchester.ac.uk providing relevant details, so we can investigate your claim.

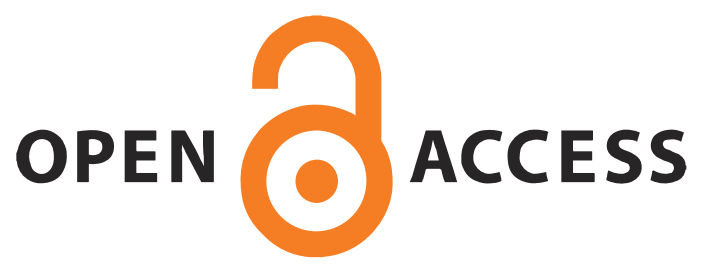




\title{
National Culture and Bank Risk-Taking
}

Stella Mourouzidou-Damtsa, Andreas Milidonis, Konstantinos Stathopoulos*

\author{
Journal of Financial Stability, forthcoming
}

\begin{abstract}
We investigate the relation between national cultural values and bank risk. Despite the rigid transnational regulatory oversight of systemic European banks, we find evidence of an economically significant association between cultural values and domestic bank risk. Specifically, we report a positive (negative) association between the cultural values of individualism and hierarchy (trust) and domestic bank risk-taking. Consistent with our predictions, this relation weakened during the recent financial crisis and does not hold for global banks, regardless of the period under investigation. Our findings are robust to endogeneity tests that mitigate concerns regarding reverse causality and confounding effects affecting our conclusions.
\end{abstract}

Keywords: Bank risk-taking; National Culture; Financial Crisis; Domestic vs. Global Banks.

JEL classifications: G01, G21, Z13.

*We are grateful to two anonymous referees and the Editor (Iftekhar Hasan) for invaluable comments and suggestions that have greatly improved the paper. We would also like to thank conference participants at IFABS 2016 and IMAEF 2016 for helpful comments on previous versions of the paper. Mourouzidou-Damtsa is a DBA candidate at Alliance Manchester Business School, The University of Manchester. Milidonis is at the Accounting and Finance Department, Faculty of Economics and Management, University of Cyprus. Stathopoulos is at Alliance Manchester Business School, The University of Manchester. Corresponding Author: Stella Mourouzidou-Damtsa, stella.mourouzidoudamtsa@postgrad.manchester.ac.uk. 


\section{Introduction}

Bank risk-taking is essential to bank performance but could become detrimental to the survival of the bank as well as the stability of a national financial system if it leads to financial crises (European Commission report, 2014). ${ }^{1}$ Given that the banking sector transmits financial instability between sovereigns (Acharya et al., 2014a), identifying new factors associated with bank risk is not only academically relevant but also helps safeguard the global financial system. This paper contributes to this important line of research by examining the role of national culture as a determinant of bank risk-taking.

The banking industry is heavily regulated. Important legislation typically stands at a transnational level, for example, the Basel Accords; therefore, it is reasonable to expect country specific characteristics, such as national cultural values, to have little or no effect on the risk assumed by banks. However, regulation is not able to fully capture the intricate dynamics affecting managerial decision-making, leaving banks with some flexibility and power over their loan granting and deposit accumulation strategies (Dothan and Williams, 1980). Furthermore, managerial perception of risk and predisposition to taking risk vary between individuals and societies (Delerue and Simon, 2009). Prior work highlights that national cultural values primarily influence risk preferences and attitude towards risk (Husted and Allen, 2008; Weber and Hsee, 1998). We argue that national culture not only influences the risk appetite of bank managers directly but also has an indirect effect since bankers should cater to the needs and risk preferences of their customers (Storey and Easingwood, 1993), who are bound to be influenced by national characteristics especially for domestic banks.

\footnotetext{
${ }^{1}$ http://ec.europa.eu/research/social-sciences/pdf/policy_reviews/KI-NA-26554_EN-C.pdf
} 
Following prior studies, we identify three national cultural values, that is, individualism, trust and hierarchy, which we expect to be associated with bank risk-taking. Countries characterised by individualistic cultural norms are known for their emphasis to individual advancement, regardless of group goals. In contrast, countries with collectivist cultures give priority to societal and work group goals over individual gain and needs. Therefore, banks operating in individualistic societies should increase risk to cater to their customer and shareholder needs whose primary objective is wealth maximization (Yahanpath, 2011) and have little consideration about the impact of bank risk to the stability of the national financial system. Shareholders benefit from increased risk-taking through its positive effect on the expected return of their investments. On the other hand, customers benefit from increased bank risk-taking since such risk-taking is typically focused on non-interest banking activities. This diversification in bank activities helps banks to increase revenues from commissions on investments (Barth et al., 2013; Lepetit et al., 2008), thus allowing them to decrease spreads between lending and saving rates, helping customers gain easier and cheaper access to debt financing. In addition to the preferences of individualistic bank stakeholders, individualistic bank managers would also favour risk taking since they value personal gain more than group benefit. Bank risk positively affects the expected value of managerial compensation packages since bank executive remuneration relies heavily on equity-based pay schemes (Hagendorff and Vallascas, 2011; Srivastav et al., 2014; Vallascas and Hagendorff, 2013). Bank managers operating in societies characterized by higher individualism will optimally increase risk even if they are foreign nationals, that is, they don't necessarily share the same national culture. This is because (a) they should cater to their stakeholder preferences and (b) individualistic societies are more tolerant towards income inequality driven by risk taking (Conyon and Murphy, 2000), thus are more likely to accept such utility maximising managerial behaviour. 
Banks operate in a competitive environment, hence building and maintaining good relationships with customers is important (Mosad, 1996). A strong bank-customer relationship enhances customer loyalty (Dick and Basu, 1994), which can be attributed, to a considerable degree, to customer trust (Dwayne et al., 2004). Customer trust is necessary for banks (Ratnovski, 2013) to maintain and increase deposits. When trust in a country's financial institutions is low, we observe the phenomenon of 'mattress cash' (Coupé, 2011), that is, significant deposit withdrawals from the domestic banking system, which limits the ability of banks to execute their primary role as financial intermediaries. The extent to which individual banks are affected depends on depositor expectations regarding the banks' failure risk. Indeed, Knell and Stix (2010) find that in times of crises trust declining and distrust rising are the primary triggers behind bank runs. Given the positive relation between bank risk-taking and failure risk as well as the importance of trust in maintaining and increasing deposits, we anticipate lower bank risk-taking in societies that place higher value to trust.

Finally, hierarchical societies form power ranks according to importance and social power. In such societies, lower ranked employees follow management instructions without questioning them, even if managerial motives are not necessarily aligned with their own (or the firm's) interests. In contrast, in egalitarian societies management and employees view themselves as equals (Brett et al., 1998), thus, employees are more likely to challenge managerial decisions. Furthermore, egalitarian societies cater for all stakeholders and the society at large, thus are more likely to be concerned about the financial stability of the banking sector. In addition, in these societies, managers need to consider the interests of all stakeholders, including lower ranked employees, as they have the potential to affect the firm (Gibson, 2000). We therefore expect that in societies characterized by hierarchical values bank risk is likely to be higher compared to that in egalitarian societies. 
Our paper argues that the anticipated relation between national culture and bank risk should weaken during global financial crises, like the recent one in 2007-2010. This happens primarily for two reasons: (a) crises increase dramatically banks' cost of borrowing, making high levels of managerial risk-taking unsustainable. In response, managers should rationally decrease bank risk-taking, irrespective of personal and national attributes or preferences; (b) we anticipate that the degrees of freedom, in which banks operate in, decrease as the sovereign entity in which they function gets externally constrained. At times of instability, sovereigns lose part of their autonomy as they become more dependent on the debt markets. This is particularly true for our sample of European banks since all banks operate in European Union member states, some of which experienced EU (externally) imposed macroeconomic and financial sector adjustment programmes. These programmes gave greater control and oversight of national financial sectors to European institutions such as the European Central Bank (ECB). As a consequence of the above listed reasons, we expect national culture to have a lesser impact on banks' financial decisions, during the recent financial crisis.

We also expect national culture to affect the risk taking of systemic domestic banks, but not that of global ones. By definition global banks operate in global settings. They are primarily multinational and interconnected (Edwards, 2012), and their multi-country presence exposes management to different national cultures, hence very diverse customer needs. Furthermore, the importance of systemic global banks to the global economy means they are subject to additional regulatory requirements, including capital, risk management and compliance requirements (Walker, 2012) reducing their flexibility and exposure to national culture influences. This is particularly true for European systemic global banks which are monitored 
and supervised directly by the ECB as opposed to domestic banks where the national regulators are allowed appropriate discretion to accommodate the structural characteristics of their country's domestic financial sector. ${ }^{2}$ Given that the national regulators are bound to be affected by and respond to national social norms, they act as an additional (to bank managers and customers) channel through which national culture affects domestic bank risk.

We empirically examine our conjectures using a sample of 99 banks in 19 European countries which we study for 20 years (1995-2014). These banks were included in the European Banking Authority (EBA) 2014 stress tests and have data in Bloomberg for at least five consecutive years. We follow prior literature (Craig and Dinger, 2013; García-Kuhnert et al., 2015; Jin et al., 2013) and use the bank's Return On Assets (ROA) volatility as our primary risk proxy. After controlling for several country, bank and managerial characteristics, we find a strong positive association between individualism (hierarchy) and domestic bank risktaking. Consistent with our conjectures, we report a strong negative relation between trust and domestic bank risk-taking. As anticipated, we also find that financial crises weaken the relation between national culture influences and bank risk, whereas this relation exists only for domestic but not global banks, regardless of the period under investigation.

Arguing in favour of a causal effect of national culture on bank risk is admittedly difficult given significant endogeneity concerns, particularly about reverse causality and confounding effects. We note that national cultures evolve slowly over very long periods and perceptions over individualism, trust and hierarchy depend on personal attributes that are deeply rooted into societal characteristics. Still, one may argue that major prior events related to the country's financial sector risk could affect perceptions over social norms leading to reverse

\footnotetext{
${ }^{2}$ http://www.bis.org/publ/bcbs233.pdf
} 
causality. A more important concern in our context relates to the impact of omitted variables to our conclusions. In particular, unobservable characteristics could be driving both national culture and bank risk, leading to spurious results. Key research design choices, for example, the use of a relatively homogeneous sample and hierarchical modelling allow us to mitigate these concerns. By controlling for a wide range of country-, bank- and manager-level determinants of bank risk, including year fix effects and using alternative variable definitions, we further alleviate the impact of omitted variables to our conjectures. Importantly, we offer a more formal way of addressing endogeneity using instrumental variable regressions, where we instrument for national culture variables and run two-stage least squares (2SLS) regressions. Collectively, our results point towards a causal effect of national culture on bank risk. Still, we concur that one cannot completely mitigate endogeneity concerns in our setting.

This paper primarily contributes to two literatures. Prior work identifies governance, institutional and financial factors as determinants of bank risk (see for example, Barth et al., 2013; Breuer, 2006; Craig and Dinger, 2013; Delis and Kouretas, 2011; Houston et al., 2010; La Porta et al., 1998; Laeven and Levine, 2009). Our paper highlights the role of an informal institution, that is, national culture, as an important determinant of domestic bank risk, thus contributing to the extant literature. Furthermore, we add new insights to the developing literature on the impact of national culture to financial decision-making (e.g., Ahern et al., 2015; Giannetti and Yafeh, 2011). There are two papers in this strand of literature that are closely related to ours (Kanagaretnam et al., 2014; Li et al., 2013). Li et al. (2013) find that culture is related to corporate risk using a sample of manufacturing firms. We are different from Li et al. in at least two ways. First, we focus on banks, which is a unique, highly regulated sector. The impact of regulation on the investigated relation leads to very different predictions ex-ante. Second, we study different dimensions of national culture, different 
countries and periods compared to Li et al. All these differences lead to new, interesting insights. Kanagaretnam et al. (2014) find that differences in national cultures affect both accounting conservatism and risk taking in banks. Our paper differs from Kanagaretnam et al. in several important ways. First, they study a sample of banks from 70 countries covering all continents. We focus on systemic European banks, which helps us better alleviate concerns about the impact of unobservable heterogeneity affecting our conclusions. Second, we investigate the relation between culture and bank risk during the recent financial crisis and find a significant weakening of the effect. In contrast, they focus on failed banks (tail risk) and present different conclusions. Third, we showcase that the predicted relation is only valid for domestic banks but not global ones. Fourth, we formally address endogeneity concerns and show that our results are robust to dealing with spurious effects and reverse causality. Finally, our analysis covers a much longer time-series (1995-2014 vs. 2000-2009) and tests various specifications as well as alternative constructs for national culture. Overall, we believe our paper makes contributions to academic knowledge that are both new and interesting.

\section{Context and Prior Work}

\subsection{Why are banks different and so important in our context?}

The banking sector has three major differences compared to non-financial companies that influence our conjectures. First, banks are information specialists enabling them to match depositors with borrowers (Boyd and Prescott, 1986; Diamond, 1984; Ramakrishnan and Thakor, 1984). Therefore, it is particularly important for financial institutions to operate within societal norms and respond to stakeholder (e.g., customers, shareholders) needs in order to remain competitive. Catering to stakeholder needs also allows banks to maintain and increase their liquidity, without which they cannot properly function. 
Second, banks are linked together via the interbank market, exposing them to contagion risk (Iori et al., 2006; Mistrulli, 2011; Upper, 2011). Under the European deposit protection scheme, contagion risk expands to the banks' corresponding sovereigns. The bailouts of banks increase sovereign credit risk in developed economies (Acharya and Rajan, 2011), erode the value of government guarantees and ignite a loop between sovereign and bank risk (Acharya et al., 2014a). Because banks hold sovereign bonds, there is also feedback in the

other direction (Attinasi et al., 2010). Given the importance of the financial sector to a country's prosperity, societies have strong interest in bank risk-taking and apply intense pressure to bank managers to conform to societal norms.

Third, banks are the major vehicle through which a country's Central Bank applies its monetary policy, that is, inflation stability, regulatory application, and expectations management, for the benefit of society (Molnár and Santoro, 2014). Consequently, it is imperative for banks to have better risk management practices (Birge and Júdice, 2013) compared to non-financial firms. Regulation has limits in capturing the complex dynamics affecting managerial decision-making in banks (Dothan and Williams, 1980; Kane, 1981), which leaves room for informal institutions, such as national culture, to influence bank risk management.

\subsection{Prior work on the determinants of bank risk}

Prior work identifies several non-cultural (financial, governance, institutional) factors affecting bank risk. Breuer (2006) studies legal, political and other institutions within countries and finds that they affect the level of non-performing bank loans. Boyd et al. (1993), Hakenes and Schnabel (2011), and Bhagat et al. (2015) find a negative correlation 
between risk-taking and bank size. Dell'Ariccia et al. (2014) and Bhagat et al. (2015) associate bank leverage, that is, the ratio of equity capital to total assets, with bank risk. Valencia (2014) also identifies capital adjustments as a potential source of increased risk via increased leverage. In addition, when interest rates decrease, the bank's net interest marginal revenue decreases motivating bank management to find alternative income sources of higher yield, thus higher risk (Delis and Kouretas, 2011). Furthermore, Craig and Dinger (2013) find that when the competition for deposits is high, banks offer higher interest rates to attract deposits resulting in increased liabilities cost which consequently raises the optimal risk choice of banks. Banks with increased cost of liabilities tend to increase lending, sometimes sacrificing quality over quantity, which could lead to instability and financial crises (Jordà et al., 2011; Wagner, 2007).

Moreover, Lepetit et al. (2008) and Barth et al. (2013) report a positive association between the level of income originating from non-traditional banking activities (i.e., commission based non-interest income) and risk-taking. Barth et al. (2013) also highlight the degree of transparency in financial statements as one of the factors linked to bank risk, whereas Houston et al. (2010) show that information sharing among creditors has significant effect in increasing bank profitability and lowering risk. Barry et al. (2011) report differences in risktaking between privately owned and public banks. Laeven and Levine (2009) highlight more subtle differences in ownership structure by showing that the cash flow rights of the largest shareholder and managerial ownership are important determinants of bank risk-taking.

Regarding the latter point, there is an extensive literature looking at the equity incentives of bank managers and how they affect bank risk-taking. For example, Hagendorff and Vallascas (2011) find that bank CEOs with higher pay-risk sensitivity (i.e., compensation vega) 
increase risk-taking by engaging in risk-inducing mergers. However, Fahlenbrach and Stulz (2011) report that compensation vega had little effect over bank performance and risk during the recent financial crisis.

\section{Data Sources}

Our sample consists of European banks selected by the EBA to perform the 2014 stress tests. ${ }^{3}$ These tests evaluate the resilience of the banking sector to systemic risk, hence focus on systemically important banks. Our research design choice to focus on systemic European banks helps us develop a relatively homogeneous sample. These banks operate under a uniform regulatory environment and share common regulators including the EBA and the European Stability Mechanism (ESM), as well as the same policymaker in the ECB. Thus, our sample selection reduces unobservable heterogeneity significantly, which helps reduce the impact of confounding effects. We have included 99 out of a total of 123 banks for which data existed in Bloomberg for at least five consecutive years. The stress-test participating banks originate from 19 European countries and cover at least $50 \%$ of the national banking sector in each EU member state in terms of 2013 consolidated assets. Our sample consists of major global financial institutions, such as Barclays, Deutsche Bank and HSBC, as well as small domestic systemic banks such as OTP Bank, SNS Bank and UBI Banka. Collectively, the banks in our sample represent more than $70 \%$ of total EU banking assets (approximately $€ 29,000 \mathrm{bn})$.

\footnotetext{
${ }^{3}$ https://www.eba.europa.eu/documents/10180/563711/31012014+EU$\underline{\text { wide }+ \text { stress }+ \text { Test }+2014+\% 28 \text { List }+ \text { of }+ \text { sample }+ \text { banks }+\% 29 . x \text { lsx }}$
} 
We study a 20-year period (1995-2014). We collect all the bank financial data from Bloomberg, ${ }^{4}$ whereas the World Values Survey provides information on national cultural values. We describe this survey and our culture constructs in detail in the next section. Finally, we use a variety of additional sources to construct control variables that prior work has identified as important determinants of bank risk. For example, we use BoardEx to collect information on bank CEO nationality. All variables used in this study are defined in Appendix A. Given the unbalanced nature of our panel and missing values for some variables there is some variation in the number of observations we report across specifications. The maximum number of bank-years under investigation is $1,345 .^{5}$

\footnotetext{
${ }^{4}$ Bloomberg is an integrated platform for financial data used by 250,000 companies (including investment firms and banks) worldwide for their own as well as their client's portfolio allocation decisions. Existing academic literature also uses it; see for example Acharya et al. (2011); Acharya and Steffen (2015); De Bruyckere et al. (2013); Thanassoulis, (2014); Thiripalraju and Acharya (2010).

${ }^{5}$ A possible criticism with investigating the impact of national culture on bank risk-taking for all current EU member states is that Cyprus, Hungary, Malta, and Poland were not members of the European Union since the beginning of our assessment period (1995). We note that these four countries account for less than $1 \%$ of our sample. Also, countries that apply for European Union membership prepare and conform to EU standards and regulations before their EU entry application. Cyprus and Malta applied for EU membership in 1990 whereas Hungary and Poland applied in 1994. Hence, all four countries applied for EU membership before 1995, that is, the starting year of our sample. In any case, our results are not sensitive to the decision to include in our analyses the banks from these countries.
} 


\subsection{National culture variables}

To measure national cultural values, we use the World Values Survey (WVS). ${ }^{6}$ It takes place in waves. ${ }^{7}$ We follow Ahern et al. (2015) in selecting the proxy survey questions for each of the three cultural variables under investigation, that is, individualism, hierarchy, and trust. Ahern et al. (2015) comment extensively on the validity of the three cultural constructs from WVS, which have been validated by other studies as well; see for example Fehr et al. (2003), Glaeser et al. (2000) and Holm and Danielson (2005). We present in Appendix A the survey questions relating to these variables as well as details on variable construction.

Following prior literature, we rescale the survey scores so that our cultural variables range between zero and one. The three cultural variables (trust, hierarchy, and individualism) do not show any statistically significant correlation, which implies that each variable captures a different dimension of national culture (unreported result). Figure 1 shows the average value of trust, hierarchy, and individualism by country. We observe significant variation between the values of the three cultural variables from one country to another. It is evident that the European club where all nineteen countries in our sample belong to is primarily a politicoeconomic union with its members maintaining their cultural identity. Trust is lowest in Cyprus, Portugal and Poland and highest in Sweden, Finland, and the Netherlands.

\footnotetext{
${ }^{6} \mathrm{WVS}$ is the largest, non-commercial academic study covering the world's major cultural zones; conducted in almost 100 countries, it covers about $90 \%$ of the world's population using a common questionnaire. This survey is run by an association headquartered in Sweden and comprises a network of social scientists. Researchers utilize WVS data extensively, with more than 400 publications making use of them.

${ }^{7}$ WVS conducted surveys over the following periods: 1981-1984, 1990-1994, 1995-1998, 1999-2004, 20052009 and 2010-2014. We use the last four waves since they correspond to our sample period, that is, 1995 to 2014.
} 
Individualism is lowest in Greece, Austria and Portugal and highest in Luxembourg, Denmark, and Malta, whereas hierarchy is lowest in Finland, Portugal, and Belgium and highest in Cyprus, Germany, and Sweden. We take advantage of this significant variation in cultural values to investigate their impact on bank risk.

(Insert Figure 1 here)

\subsection{Proxies for bank risk}

Our main proxy for bank risk is the volatility of Return on Assets (ROA). Following Craig and Dinger (2013), García-Kuhnert et al. (2015) and Jin et al. (2013), we define it as the fiveyear volatility of the ratio of the gross pre-tax profit (including loan loss provisions) to total assets. Increased volatility in ROA implies a higher level of risk. To control for extreme values, we use the logarithmically transformed ROA volatility in our regression analysis. However, we note that our regression results are not sensitive to this decision and remain if we use the raw ROA volatility values. In Figure 2, we plot risk (ROA volatility) and returns (ROA level) by country. The highest ROA volatility is in Greece, followed by Cyprus and Poland, which is anticipated given the recent financial crisis in these countries, particularly, Greece and Cyprus. Increased risk does not necessarily translate into higher return. The countries with the highest average bank ROA during our time-series are Hungary followed by Poland and Malta. Clearly, the return to risk ratio differs significantly from one country to the other.

(Insert Figure 2 here)

In robustness checks we also use the banks' z-score as an alternative proxy for risk, following Beltratti and Stulz (2012), Boyd et al. (1993), Boyd and De Nicollo (2005), Houston et al. 
(2010), Laeven and Levine (2009) and Tonzer (2015). The z-score measures the distance from insolvency in standard deviations and is defined as the Return on Assets (ROA) ratio plus the Capital Asset Ratio (CAR) divided by the standard deviation of ROA, on a five-year basis. To deal with extreme values, we also use the logarithmic transformation for z-score. In contrast to the ROA volatility, higher z-scores imply lower probability of insolvency, hence lower risk. To facilitate exposition, we multiply the log transformed z-score values by minus one.

Following Bushman and Williams (2012), Jin et al. (2013) and Makri and Papadatos (2014), our third alternative proxy for bank risk is Loan Loss Provisions. Loan Loss Provisions is the ratio of the loan loss provisions to loans, a measure of the quality of loans granted by banks. Bank asset quality has been responsible for bank failures, and we, therefore, use it as a proxy for risk. Consistent with the treatment of our other risk proxies, we use the logarithmically transformed values in our regression analysis. The use of the loan loss provisions measure allows us to address a caveat with the other two measures since their estimation depends on 5-year windows. This makes claims over a contemporaneous relation more difficult, and hinders the interpretation of our sub-period analyses. The loan loss provision measure addresses both issues since it is estimated annually.

\subsection{Control variables}

In line with other studies on bank risk taking, we control for bank characteristics such as size (Boyd et al., 1993), leverage (García-Kuhnert et al., 2015), net interest marginal revenue (Hellmann et al., 2000) and interest activity (Demirgüç-Kunt and Huizinga, 2010). We also control for country characteristics that might have a high correlation with our cultural value constructs and ultimately drive our results (i.e., confounding effects). To capture cross- 
country differences, we use macroeconomic, legislative and institutional data. We follow Ahern et al. (2015), Anginer et al. (2014), Fiordelisi et al. (2011), La Porta et al. (1997) and Li et al. (2013) in choosing the relevant country variables (e.g., GDP per capita, GDP growth volatility, Domestic credit as a percentage of GDP, Legal origin). We collect the information from the World Bank database, as well as the relevant academic papers directly (e.g., La Porta et al. (1998) for legal origin).

Following Barry et al. (2011), we control for whether a bank is listed on a stock exchange or not. We also control for the degree of restriction of non-traditional banking activities in a country, the degree of transparency in bank financial statements, and a country-level index of banks' capital adequacy under adverse conditions (Barth et al., 2013). Furthermore, we include a cash flow index and the ownership level of senior managers, which allow us to capture the cash flow rights of the largest shareholder and senior management, respectively (Laeven and Levine, 2009). In addition, we add the index capturing the information sharing among creditors by Djankov et al. (2007). Lastly, we control for the nationality of the bank's CEO. We record the nationality of the CEOs on an annual basis for each bank in our sample using the Boardex database. ${ }^{8}$ All variables are defined in Appendix A.

\subsection{Descriptive statistics}

Table 1 provides the descriptive statistics for our sample. We report the mean, standard deviation, median, $25^{\text {th }}$ percentile and $75^{\text {th }}$ percentile for each variable. We group the variables into dependent, cultural, country, bank financials and other.

\footnotetext{
${ }^{8}$ We find that the CEO is a national of the bank's headquartering country in more than $90 \%$ of our observations. Thus, differences between the cultural norms of the CEOs and the societies their banks operate in are unlikely to drive our findings on national culture and domestic bank risk.
} 
Starting with the dependent variables, we observe that ROA volatility has an average (median) of $0.38(0.23)$. Similarly the average (median) value for z-score is 4.50 (2.68). In principle, this median value indicates that European systemic banks during the period 1995 to 2014 were less healthy than banks globally since the z-score is below the median of 3.567 reported by Kanagaretnam et al. (2014) in their study covering 70 countries and approximately 900 banks from 2000 to 2006 . However, such comparison is misleading given the limited time-series coverage in Kanagaretnam et al. (2014), which ignores the recent financial crisis period. Finally, the loan loss provisions average is 0.08 higher than the 0.03 reported by Kanagaretnam et al., (2014) indicating that European systemic banks for the period 1995 to 2014 have a higher loan loss provisions to total loans ratio compared to banks globally (for the period 2000-2006), which at first sight appears to be counterintuitive. Again, this difference is likely attributable to the significant discrepancies in terms of time-series coverage between the two studies and highlights the need for large samples covering significant macro events when conducting studies based on international settings.

Turning to the variables proxying cultural characteristics, we observe that individualism and hierarchy have similar values for mean ( 0.53 and 0.49 , respectively) and standard deviation ( 0.08 for both), while trust is characterized by much more variation (standard deviation is 0.14 ), whereas the average value is 0.35 .

(Insert Table 1 here)

The descriptive statistics for the control variables, i.e., bank and country characteristics, are consistent with those reported in prior work. We note that the average values for the bank- 
and country-size proxies (e.g., bank size and GDP per capita) are relatively high which is an artefact of our decision to study systemic banks in EU (wealthy) nations.

\section{Methodology}

We apply a hierarchical/multilevel linear modelling approach to test our hypotheses. There are three levels in the data: countries, banks, and observations. To explore these multilevel data and account for the clustered structure of the dataset we employ a hierarchically nested form of the general linear model; see Goldstein (2011) and Raudenbush and Bryk (2002). The hierarchical approach separates the variance attributable to bank and country level variables. Thus, homogeneity is not a prerequisite. Multilevel models take into account the sample size within a country by applying weights, and accurately include cross-level interactions between the bank- and country-level variables (Li et al., 2013). According to Field (2013), errors in these models need not be independent, and inputting or deleting missing data is not necessary. Multilevel linear models can correctly group bank-level effects across countries while also examining country-level relations.

We divide our sample into three periods in order to study the impact of the recent financial crisis to the relation under investigation: the full sample is 1995 to 2014 ; the non-crisis sample is 1995 to 2006 and 2011 to 2014 , whereas the crisis sample is 2007 to 2010 . We define the recent financial crisis period following existing literature that has studied banks during the global financial crisis; see for example Choi (2013), Dabrowski (2010), Gilbert et al. (2012) and Mirzaei (2013).

To study the relation between bank risk-taking and cultural values we regress bank risk on cultural, country and bank financial variables for each of the periods under assessment: 


$$
\begin{gathered}
\text { Bank Risk }_{\mathrm{i}, \mathrm{j}, \mathrm{t}}=\alpha+\beta(\text { Cultural Variables })_{\mathrm{j}, \mathrm{t}}+\gamma(\text { Country Variables })_{\mathrm{j}, \mathrm{t}}+\delta(\text { Bank Financial } \\
\text { Variables })_{\mathrm{i}, \mathrm{j}, \mathrm{t}}+\zeta(\text { Other Controls })_{\mathrm{i}, \mathrm{j}, \mathrm{t}}+\text { Year FE }+\varepsilon_{\mathrm{i}, \mathrm{j}, \mathrm{t}}
\end{gathered}
$$

The main dependent variable (Bank Risk $\mathrm{i}_{\mathrm{i}, \mathrm{j}, \mathrm{t}}$ ) for bank $\mathrm{i}$ in country $\mathrm{j}$ at time $\mathrm{t}$ is the ROA volatility. Vector $\beta$ captures the national culture variables for country $\mathrm{j}$ at time t. Vector $\gamma$ captures macroeconomic and other country-level variables for country $\mathrm{j}$ at time t. Vector $\delta$ captures the bank financial variables for bank $\mathrm{i}$ in country $\mathrm{j}$ at time $\mathrm{t}$, whereas vector $\zeta$ includes other controls such as managerial ownership, capital adequacy under adverse conditions and legal origin.

During 1995-2014, market valuations changed considerably and macroeconomic shocks (e.g., currency crisis) took place, which affected bank risk at the global level. Hence, we include year fixed effects to control for time effects. ${ }^{9}$

\footnotetext{
${ }^{9}$ Most recent academic papers use hierarchical models when dealing with multilevel cross-country data (e.g., Bakar et al., 2017; Dong and Stettler, 2011; Kayo and Kimura, 2011; Ketelhöhn and Quintanilla, 2012; Li et al., 2013; Mihet, 2013). However, it is also common to run OLS regressions with country and/or firm dummies, to capture country/firm time-invariant (fixed) effects. All our results are insensitive to this modelling choice and our findings remain unchanged when running OLS regressions with country/bank fixed effects (unreported analysis; results are available from the authors upon request). Still, we do not report this analysis not only because we wish to conserve space but also feel that hierarchical models better capture heterogeneity in our setting (i.e., three levels of clustered observations).
} 


\section{Empirical Results}

\subsection{Multilevel tests}

Table 2 presents the multilevel linear regression results for all banks. For the whole timeseries (column 1), we find a strong relation between the three cultural values and bank risk after controlling for a variety of country, bank and manager characteristics. All three cultural variables, namely, individualism, trust, and hierarchy are statistically significant at $1 \%$. Consistent with our conjectures, individualism and hierarchy are positively associated with bank risk while trust is negatively related to risk. The findings indicate a non-trivial economic effect of national culture on bank risk. In particular, a one standard deviation increase in individualism around its mean $\left(25^{\text {th }}\right.$ to the $75^{\text {th }}$ percentile $)$ is associated with an increase in ROA volatility by $11.5 \%$ relative to the unconditional average ROA volatility $(0.38)$ in our sample. The magnitude of the economic effect is even larger for trust (decrease in ROA volatility by $18.1 \%$ ) and hierarchy (increase in ROA volatility by $14 \%$ ).

We then focus to the non-financial crisis period (column 2), which we anticipate to be the sub-period driving our results on the whole sample. Indeed, the significant relationship between the three cultural values and risk remains in that period. All cultural variables maintain their statistical significance at $1 \%$, and have the predicted signs. Furthermore, all three coefficients are now higher than the corresponding coefficients for the full sample, which is an initial indication that the result is weaker during the financial crisis period. We next turn our attention to the financial crisis sample to corroborate this conjecture.

We follow Choi (2013), Dabrowski (2010), Gilbert et al. (2012) and Mirzaei (2013) in our definition of the financial crisis period (2007-2010). We re-run our main model specification and find no statistically significant association between the three cultural variables and bank 
risk during the financial crisis. As mentioned previously, banks become more constrained during financial crises as a result of the significant increase in their borrowing costs. Therefore, bank managers will adapt their risk management policies in response to the macroeconomic uncertainty regardless of societal norms relating to risk taking. At the same time, during financial crises, sovereigns lose part of their autonomy as they become more dependent on the debt markets as well as the support of other states. The latter is particularly relevant in our sample of European banks, many of which had to rely on European-wide bail out mechanisms that applied directly to them or their sovereigns, e.g., Spain, Ireland, Portugal, Greece, and Cyprus. Under these mechanisms, European institutions, such as the ECB and the ESM, took a prominent role in coordinating the efforts of steering the European financial sector out of the crisis, which significantly weakened the impact of informal national institutions, such as cultural norms, on bank risk taking. Overall, our results are consistent with national culture having a lesser impact on the bank financial decisions due to the above constraints. We note here that the lack of significant results during the crisis period could be an artefact of our decision to study systemic banks, which were under intense scrutiny and the focus of European institutions during this period. It might be the case that there was still a significant, albeit weakened, relation between cultural values and bank risk for peripheral (non-systemic) banks that were less likely to be under the scrutiny of European regulators and policy makers. Examining the differences in the national culture-bank risk relation between systemic and non-systemic banks is an interesting direction for future research.

(Insert Table 2 here)

Next, we turn our attention to verifying our predictions regarding the differential effect of national culture on domestic vs. global banks. In particular, as mentioned previously, we 
expect national culture to affect risk in domestic, but not global, banks. To test this conjecture we run our main analysis separately for domestic and global banks. According to the Basel Committee on banking supervision, the failure of G-SIBs (Global Systemically Important Banks) has worldwide consequences whereas failure of D-SIBs (Domestically Systemically Important Banks) has financial implications domestically. Hence, global banks are the primary focus of transnational regulations and operate under more stringent requirements, including higher capital requirements, and stricter risk management and compliance, which is particularly true for G-SIBs (Walker, 2012). Furthermore, they are exposed to stakeholders from many different countries, thus, the cultural norms of an individual country are bound to have limited effect on the risk-taking of global bank managers. Thus, if there is a causal relation between national culture and bank risk one would anticipate this to exist only among domestic banks but not global ones.

We start off this analysis in Table 3 by presenting multilevel linear regression results for all domestic banks in our sample for each of the three time periods under assessment. We use the Basel Committee definitions to distinguish between domestic and global banks. Consistent with the results reported in Table 2, all three cultural variables are statistically significant for the whole time-series as well as the non-crisis period, and have the predicted signs. Similar to the previous analysis, we find no significant correlation between the three cultural variables and domestic bank risk during the crisis period.

(Insert Table 3 here)

Table 4 presents our regression results on global banks. There are twelve G-SIBs $(12 \%$ of the sample) which account for $59 \%$ of the total assets of all ninety-nine systemic banks in our 
sample. None of the three cultural variables is statistically significant for the whole period and/or the non-financial crisis period. The results remain insignificant during the crisis period, but we do not tabulate them since the small sample size (40 observations only), leads to fewer degrees of freedom and little confidence about the validity of this analysis. We note here that sample size is a concern for all the analysis relating to global banks but for the noncrisis and overall samples we have a sufficient number of observations to get valid specifications. Overall, the results reported in Tables 3 and 4 are intuitive and confirm our conjectures regarding the role of national culture.

(Insert Table 4 here)

\section{Robustness checks}

\subsection{Alternative bank risk proxies}

To test the robustness of our results, we use two alternative proxies for bank risk, the z-score which measures the distance from insolvency in standard deviations and the loan loss provisions as per Bushman and Williams (2012) and Makri and Papadatos (2014). The use of alternative risk measures helps us strengthen our inferences since unobservable effects are not expected to be similarly correlated to all three measures. Therefore, this analysis helps alleviate the concern that common confounding factors might be driving our findings. We report the results of this analysis in Panels $\mathrm{A}$ and $\mathrm{B}$ of Table 5. The three cultural variables remain statistically and economically significant for the whole sample regardless of the choice of dependent variable. The only exception is the coefficient of hierarchy when using loan loss provisions as our dependent variable, which has the anticipated sign but is now insignificant. The results are driven again by the non-crisis period and are not statistically significant during the crisis period (the coefficient of hierarchy is marginally significant, at 
10\% level, in Panel B). In untabulated analysis, we further confirm that the effect exists only for domestic banks (D-SIBs) but not for global banks (G-SIBs). Overall, our findings are not overly sensitive to the choice of a particular proxy for bank risk.

(Insert Table 5 here)

We also considered using Risk Weighted Assets as an alternative proxy for bank risk. However, only a small number of banks in our sample began reporting this measure in 2004 (mainly global banks). This number increased in 2008 and by 2011 nearly all banks included this measure in their financial accounts. However, given the limited availability of data and the criticism this specific measure has received recently (Acharya et al., 2014b), we refrain from using it as an alternative risk proxy in this context.

\subsection{Endogeneity}

To formally address concerns regarding the impact of omitted variables (i.e., confounding effects) to our conclusions, we conduct two-stage least squares (2SLS) regressions by selecting instrumental variables (IVs) for our national culture variables (i.e., individualism, trust and hierarchy). We carefully select IVs that are expected to correlate with the first stage dependent variables but not the second stage error term.

We follow prior literature and employ established measures that have been used as instrumental variables for national culture in similar settings. In particular, Alesina et al. (2003) instrument national culture using three fractionalization measures, that is, ethnicity, language and religion. A fourth instrument (Geography) comes from Kwok and Solomon (2006) and captures the geographical divergence of the underlying country. To test if the IVs 
are appropriate for our model, we use the approach described by Baum et al. (2011) for under-identification, weak-identification and over-identification. The four instruments are used as proxies for each of the national culture variables (i.e., individualism, trust and hierarchy). In addition we separately run redundancy tests for IVs.

Table 6, Panel A, shows the results of these redundancy tests. Since the null hypothesis of the redundancy test is that each IV is redundant, rejecting this hypothesis validates its inclusion in the analysis. As shown in Panel A, all tests reject the null hypothesis of redundancy (with p-values less than 0.01). These results are not surprising given that prior studies have validated our choice of instruments. In particular, Li et al. (2013) shows that ethnicity, language, religion and geography are important determinants of cultural values hence satisfy the relevance criterion. At the same time, we expect them to influence bank risk-taking only through cultural norms, therefore they should also satisfy the exclusion criterion.

(Insert Table 6 here)

As mentioned above, to further strengthen our conjectures we run a series of additional identification tests which validate the use of the chosen IVs (untabulated). Specifically the hypothesis of weak IVs is rejected by both the Cragg-Donald and Kleibergen-Paap test statistics, since they are both above the Staiger and Stock (1997) cut-off points used as benchmark for rejecting the weak IV hypothesis. Similarly, the Cragg-Donald and Kleibergen-Paap test statistics further reject the weak IV hypothesis when benchmarked against the threshold for relative bias and relative size (Stock and Yogo, 2005). ${ }^{10}$ Moreover,

\footnotetext{
10 The Stock and Yogo (2005) method requires " $n+2$ " instrumental variables relative to the number of endogenous regressors $(n)$. Hence, we cannot identify the Stock and Yogo cut-offs in our main IV specification
} 
the over-identification test (Hansen J-statistic) has a p-value above 0.10 ; hence we can safely conclude that our instruments also satisfy the over-identification criterion too.

Since all identification tests indicate the validity of our instruments, we can now focus on the significance of the three endogenous cultural regressors (individualism, trust and hierarchy). We find that their coefficients remain statistically significant at the $1 \%$ level and with the expected sign. Therefore, even though we cannot completely rule out endogeneity, we argue that these results mitigate concerns about omitted variable bias driving our findings.

In this paper we argue that national culture affects bank risk-taking. We do not anticipate the reverse relation (i.e., bank risk to affect national culture) to hold since national cultural norms are established over a very long period, whereas bank risk is volatile and varies in the timeseries. Furthermore, perceptions over individualism, trust and hierarchy depend on personal attributes that are deeply rooted into societal characteristics. Still, to address reverse causality concerns we run an additional test; instead of using national culture constructs based on the responses to the World Value Survey which takes place in waves thus allows for time-series variation in cultural values, we re-run our analysis using static proxies for culture. In particular, we follow Kanagaretnam et al. (2014) and use the Hofstede individualism and uncertainty avoidance values. Hofstede (2001) defines individualism as over-optimism and overconfidence and hence it is expected to have a positive relation to risk. Uncertainty

given that we have 3 endogenous regressors but only 4 instrumental variables. In unreported analysis, we have experimented with the number of instrumental variables in our tests, adding one variable used in prior literature (e.g., "Somatic Distance" (Guiso et al., 2009)) in order to get the Stock and Yogo critical values. In all our tests, these critical values are below 10, which give us further confidence about the validity of our instruments. However, we do not report this specification since it does not satisfy the over-identification test. 
avoidance is defined as preferring to opt for an event with a higher occurrence probability. Uncertainty avoidance is linked to conservatism and hence is expected to have a negative association to risk. Importantly, the Hofstede measures are static during our time period, thus cannot be affected by in-sample variation in bank risk. Our results are consistent with our conjectures (untabulated). We find a positive association between individualism and domestic bank risk and a negative relation between uncertainty avoidance and domestic bank risk during non-crisis times. We find no statistically significant association between the two Hofstede national culture variables and domestic bank risk during the recent financial crisis. We also fail to find a significant association for global banks regardless of the period under investigation. Thus, we conclude that our results are not sensitive to the use of time-invariant proxies for national culture, which helps alleviate concerns about reverse causality inferences.

\section{Conclusion}

Cultural values have deep roots in societies and affect financial decision-making. In this study, we focus on three cultural values that we expect to be associated with bank risk-taking: individualism, hierarchy, and trust. Using a sample of 99 banks in 19 European countries over the period 1995 to 2014, we find that these cultural values are important and economically significant determinants of domestic bank risk. Specifically, we find a strong positive (negative) association between individualism, hierarchy (trust) and bank risk-taking.

Consistent with our expectations, we find that this association between cultural values and bank risk-taking does not apply to global banks and during periods of financial crises. Our results are robust to several specifications, which include a variety of control variables as 
well as alternative definitions for the main dependent and independent variables. Our findings are also robust to tests designed to alleviate endogeneity concerns.

This research has implications for bank shareholders when deciding the remuneration schemes of their managers and CEOs. Compensation contracts need to account for the influence of the informal institution we identify in this paper (i.e., national culture) on managerial behaviour. Our findings are also informative for bank regulators who need to take the association between national culture and risk predisposition into account, particularly, given the imminent European banking union. The impact of national culture on the decision making of national regulators, in particular with respect to their implementation of transnational rules at the national level, should be of significant interest. Lastly, our results have some implications for the investment portfolio allocation of bank stakeholders including shareholders, bondholders, and, perhaps more importantly, depositors in their bank selection. 


\section{References}

ACHARYA, V., DRECHSLER, I. \& SCHNABL, P. 2014a. A Pyrrhic Victory? Bank Bailouts and Sovereign Credit Risk. The Journal of Finance, 69, 2689-2739.

ACHARYA, V., ENGLE, R. \& PIERRET, D. 2014b. Testing macroprudential stress tests: The risk of regulatory risk weights. Journal of Monetary Economics, 65, 36-53.

ACHARYA, V. V. \& RAJAN, R. G. 2011. Sovereign debt, government myopia, and the financial sector. St. Louis: Federal Reserve Bank of St Louis.

ACHARYA, V. V., SHIN, H. S. \& YORULMAZER, T. 2011. Crisis Resolution and Bank Liquidity. The Review of Financial Studies, 24, 2166-2205.

ACHARYA, V. V. \& STEFFEN, S. 2015. The "greatest" carry trade ever? Understanding eurozone bank risks. Journal of Financial Economics, 115, 215-236.

AHERN, K. R., DAMINELLI, D. \& FRACASSI, C. 2015. Lost in translation? The effect of cultural values on mergers around the world. Journal of Financial Economics, 117, 165-189.

ALESINA, A., DEVLEESCHAUWER, A., EASTERLY, W., KURLAT, S. \& WACZIARG, R. 2003. Fractionalization. Journal of Economic Growth, 8, 155-194.

ANGINER, D., DEMIRGUC-KUNT, A. \& ZHU, M. 2014. How does deposit insurance affect bank risk? Evidence from the recent crisis. Journal of Banking \& Finance, 48, 312-321.

ATTINASI, M.-G., CHECHERITA, C. \& NICKEL, C. 2010. What explains the surge in Euro area sovereign spreads during the financial crisis of 2007-09? Public Finance \& Management, 10, 595-645.

BAKAR, J. A., CLEMES, M. D. \& BICKNELL, K. 2017. A comprehensive hierarchical model of retail banking. International Journal of Bank Marketing, 35, 662-684.

BARRY, T. A., LEPETIT, L. \& TARAZI, A. 2011. Ownership structure and risk in publicly held and privately owned banks. Journal of Banking \& Finance, 35, 1327-1340.

BARTH, J. R., CAPRIO, G., JR. \& LEVINE, R. 2013. Bank regulation and supervision in 180 countries from 1999 to 2011. Journal of Financial Economic Policy, 5, 111-219.

BAUM, C., SCHAFFER, M. E. \& STILLMAN, S. 2011. Using Stata for Applied Research: Reviewing its Capabilities. Journal of Economic Surveys, 25, 380-394.

BELTRATTI, A. \& STULZ, R. M. 2012. The credit crisis around the globe: Why did some banks perform better? Journal of Financial Economics, 105, 1-17.

BHAGAT, S., BOLTON, B. \& LU, J. 2015. Size, leverage, and risk-taking of financial institutions. Journal of Banking \& Finance, 59, 520-537.

BIRGE, J. R. \& JÚDICE, P. 2013. Long-term bank balance sheet management: Estimation and simulation of risk-factors. Journal of Banking \& Finance, 37, 4711-4720.

BOYD, J. H. \& DE NICOLLO, G. 2005. The Theory of Bank Risk Taking and Competition Revisited. Journal of Finance, 60, 1329-1343.

BOYD, J. H., GRAHAM, S. L. \& HEWITT, R. S. 1993. Bank holding company mergers with nonbank financial firms: Effects on the risk of failure. Journal of Banking \& Finance, 17, 43-63.

BOYD, J. H. \& PRESCOTT, E. C. 1986. Financial intermediary coalitions. Journal of Economic Theory, 38, 211-232.

BRETT, J., ADAIR, W., LEMPEREUR, A., OKUMURA, T., SHIKHIREV, P., TINSLEY, C. \& LYTLE, A. 1998. Culture and Joint Gains in Negotiation. Negotiation Journal, $14,61-86$.

BREUER, J. B. 2006. Problem bank loans, conflicts of interest, and institutions. Journal of Financial Stability, 2, 266-285. 
BUSHMAN, R. M. \& WILLIAMS, C. D. 2012. Accounting discretion, loan loss provisioning, and discipline of Banks' risk-taking. Journal of Accounting and Economics, 54, 1-18.

CHOI, J. W. 2013. The 2007-2010 U.S. financial crisis: Its origins, progressions, and solutions. The Journal of Economic Asymmetries, 10, 65-77.

CONYON, M. J. \& MURPHY, K. J. 2000. The Prince and the Pauper? CEO Pay in the United States and United Kingdom. The Economic Journal, 110, 640-671.

COUPÉ, T. 2011. Mattresses versus Banks - The Effect of Trust on Portfolio Composition. Kyiv School of economics and Kyiv economics institute Discussion Paper.

CRAIG, B. R. \& DINGER, V. 2013. Deposit market competition, wholesale funding, and bank risk. Journal of Banking \& Finance, 37, 3605-3622.

DABROWSKI, M. 2010. The global financial crisis: Lessons for European integration. Economic Systems, 34, 38-54.

DE BRUYCKERE, V., GERHARDT, M., SCHEPENS, G. \& VANDER VENNET, R. 2013. Bank/sovereign risk spillovers in the European debt crisis. Journal of Banking \& Finance, 37, 4793-4809.

DELERUE, H. \& SIMON, E. 2009. National cultural values and the perceived relational risks in biotechnology alliance relationships. International Business Review, 18, 1425.

DELIS, M. D. \& KOURETAS, G. P. 2011. Interest rates and bank risk-taking. Journal of Banking \& Finance, 35, 840-855.

DELL'ARICCIA, G., LAEVEN, L. \& MARQUEZ, R. 2014. Real interest rates, leverage, and bank risk-taking. Journal of Economic Theory, 149, 65-99.

DEMIRGÜÇ-KUNT, A. \& HUIZINGA, H. 2010. Bank activity and funding strategies: The impact on risk and returns. Journal of Financial Economics, 98, 626-650.

DIAMOND, D. W. 1984. Financial Intermediation and Delegated Monitoring. Review of Economic Studies, 51, 393-414.

DICK, A. S. \& BASU, K. 1994. Customer Loyalty: Toward an Integrated Conceptual Framework. Journal of the Academy of Marketing Science, 22, 99-113.

DJANKOV, S., MCLIESH, C. \& SHLEIFER, A. 2007. Private credit in 129 countries. Journal of Financial Economics, 84, 299-329.

DONG, M. \& STETTLER, A. 2011. Estimating firm-level and country-level effects in crosssectional analyses: An application of hierarchical modeling in corporate disclosure studies. The International Journal of Accounting, 46, 271-303.

DOTHAN, U. \& WILLIAMS, J. 1980. Banks, bankruptcy, and public regulation. Journal of Banking \& Finance, 4, 65-87.

DWAYNE, B., SIMÕES, P. \& ALEXANDRA, M. 2004. The role of communication and trust in explaining customer loyalty: An extension to the ECSI model. European Journal of Marketing, 38, 1272-1293.

EDWARDS, J. M. 2012. A model law framework for the resolution of G-SIFIs. Capital Markets Law Journal, 7, 122-150.

FAHLENBRACH, R. \& STULZ, R. M. 2011. Bank CEO incentives and the credit crisis. Journal of Financial Economics, 99, 11-26.

FEHR, E., FISCHBACHER, U., SCHUPP, J., VON ROSENBLADT, B. \& WAGNER, G. G. 2003. A Nationwide Laboratory Examining Trust and Trustworthiness by Integrating Behavioural Experiments into Representative Surveys. St. Louis: Federal Reserve Bank of St Louis.

FIELD, A. P. 2013. Discovering statistics using IBM SPSS statistics : and sex and drugs and rock ' $n$ ' roll / Andy Field, London, London: SAGE. 
FIORDELISI, F., MARQUES-IBANEZ, D. \& MOLYNEUX, P. 2011. Efficiency and risk in European banking. Journal of Banking \& Finance, 35, 1315-1326.

GARCÍA-KUHNERT, Y., MARCHICA, M.-T. \& MURA, R. 2015. Shareholder diversification and bank risk-taking. Journal of Financial Intermediation, 24, 602635.

GIANNETTI, M. \& YAFEH, Y. 2011. Do Cultural Differences Between Contracting Parties Matter? Evidence from Syndicated Bank Loans. Management Science, 58, 365-383.

GIBSON, K. 2000. The Moral Basis of Stakeholder Theory. Journal of Business Ethics, 26, 245-257.

GILBERT, R. A., KLIESEN, K. L., MEYER, A. P. \& WHEELOCK, D. C. 2012. Federal Reserve Lending to Troubled Banks During the Financial Crisis, 2007-2010. Review Federal Reserve Bank of St. Louis, 94, 221-D.

GLAESER, E. L., LAIBSON, D. I., SCHEINKMAN, J. A. \& SOUTTER, C. L. 2000. Measuring trust. Quarterly Journal of Economics, 115, 811-846.

GOLDSTEIN, H. 2011. Multilevel statistical models, John Wiley \& Sons.

GUISO, L., SAPIENZA, P. \& ZINGALES, L. 2009. Cultural biases in economic exchange? The Quarterly Journal of Economics, 124, 1095-1131.

HAGENDORFF, J. \& VALLASCAS, F. 2011. CEO pay incentives and risk-taking: Evidence from bank acquisitions. Journal of Corporate Finance, 17, 1078-1095.

HAKENES, H. \& SCHNABEL, I. 2011. Bank size and risk-taking under Basel II. Journal of Banking \& Finance, 35, 1436-1449.

HELLMANN, T. F., MURDOCK, K. C. \& STIGLITZ, J. E. 2000. Liberalization, Moral Hazard in Banking, and Prudential Regulation: Are Capital Requirements Enough? American Economic Review, 90, 147-165.

HOFSTEDE, G. H. 2001. Culture's consequences: comparing values, behaviors, institutions, and organizations across nations. Thousand Oaks, California. London: Sage.

HOLM, H. J. \& DANIELSON, A. 2005. Tropic Trust Versus Nordic Trust: Experimental Evidence From Tanzania And Sweden. The Economic Journal, 115, 505-532.

HOUSTON, J. F., LIN, C., LIN, P. \& MA, Y. 2010. Creditor rights, information sharing, and bank risk taking. Journal of Financial Economics, 96, 485-512.

HUSTED, B. W. \& ALLEN, D. B. 2008. Toward a Model of Cross-Cultural Business Ethics: The Impact of Individualism and Collectivism on the Ethical Decision-Making Process. Journal of Business Ethics, 82, 293-305.

IORI, G., JAFAREY, S. \& PADILLA, F. G. 2006. Systemic risk on the interbank market. Journal of Economic Behavior \& Organization, 61, 525-542.

JIN, J. Y., KANAGARETNAM, K., LOBO, G. J. \& MATHIEU, R. 2013. Impact of FDICIA internal controls on bank risk taking. Journal of Banking \& Finance, 37, 614-624.

JORDÀ, Ò., SCHULARICK, M. \& TAYLOR, A. M. 2011. Financial Crises, Credit Booms, and External Imbalances: 140 Years of Lessons. IMF Economic Review, 59, 340-378.

KANAGARETNAM, K., CHEE YEOW, L. \& LOBO, G. J. 2014. Influence of National Culture on Accounting Conservatism and Risk-Taking in the Banking Industry. Accounting Review, 89, 1115-1149.

KANE, E. J. 1981. Accelerating Inflation, Technological Innovation, and the Decreasing Effectiveness of Banking Regulation. Journal of Finance, 36, 355-367.

KAYO, E. K. \& KIMURA, H. 2011. Hierarchical determinants of capital structure. Journal of Banking \& Finance, 35, 358-371.

KETELHÖHN, N. W. \& QUINTANILLA, C. 2012. Country effects on profitability: A multilevel approach using a sample of central american firms. Journal of Business Research, 65, 1767-1772. 
KNELL, M. \& STIX, H. 2010. Trust in Banks? Evidence from normal times and from times of crises. ONB Working Paper, 158, 1-49.

KWOK, C. C. Y. \& SOLOMON, T. 2006. National Culture and Financial Systems. Journal of International Business Studies, 37, 227-247.

LA PORTA, R., LOPEZ-DE-SILANES, F., SHLEIFER, A. \& VISHNY, R. W. 1997. Legal Determinants of External Finance. The Journal of Finance, 52, 1131-1150.

LA PORTA, R., LOPEZ-DE-SILANES, F., SHLEIFER, A. \& VISHNY, R. W. 1998. Law and finance. Journal of Political Economy, 106, 1113-1155.

LAEVEN, L. \& LEVINE, R. 2009. Bank governance, regulation and risk taking. Journal of Financial Economics, 93, 259-275.

LEPETIT, L., NYS, E., ROUS, P. \& TARAZI, A. 2008. Bank income structure and risk: An empirical analysis of European banks. Journal of Banking \& Finance, 32, 1452-1467.

LI, K., GRIFFIN, D., YUE, H. \& ZHAO, L. 2013. How does culture influence corporate risktaking? Journal of Corporate Finance, 23, 1-22.

MAKRI, V. \& PAPADATOS, K. 2014. How accounting information and macroeconomic environment determine credit risk? Evidence from Greece. International Journal of Economic Sciences and Applied Research, 7, 129-143.

MIHET, R. 2013. Effects of culture on firm risk-taking: A cross-country and cross-industry analysis. Journal of Cultural Economics, 37, 109-151.

MIRZAEI, A. 2013. Bank Performance during the Financial Crisis 2007-2010. International Journal of Business and Economics, 12, 27-44.

MISTRULLI, P. E. 2011. Assessing financial contagion in the interbank market: Maximum entropy versus observed interbank lending patterns. Journal of Banking \& Finance, $35,1114-1127$.

MOLNÁR, K. \& SANTORO, S. 2014. Optimal monetary policy when agents are learning. European Economic Review, 66, 39-62.

MOSAD, Z. 1996. Bank-corporate client "partnership" relationship: benefits and life cycle. International Journal of Bank Marketing, 14, 14-22.

RAMAKRISHNAN, R. T. S. \& THAKOR, A. V. 1984. Information Reliability and a Theory of Financial Intermediation. Review of Economic Studies, 51, 415-432.

RATNOVSKI, L. 2013. Liquidity and transparency in bank risk management. Journal of Financial Intermediation, 22, 422-439.

RAUDENBUSH, S. W. \& BRYK, A. S. 2002. Hierarchical linear models: Applications and data analysis methods, Sage.

SRIVASTAV, A., ARMITAGE, S. \& HAGENDORFF, J. 2014. CEO inside debt holdings and risk-shifting: Evidence from bank payout policies. Journal of Banking \& Finance, 47, 41-53.

STAIGER, D. \& STOCK, J. H. 1997. Instrumental Variables Regression with Weak Instruments. Econometrica, 65, 557-586.

STOCK, J. \& YOGO, M. 2005. Testing for Weak Instruments in Linear IV Regression. In: Andrews DWK Identification and Inference for Econometric Models. New York: Cambridge University Press, 80-108.

STOREY, C. \& EASINGWOOD, C. 1993. The Impact of the New Product Development Project on the Success of Financial Services. The Service Industries Journal, 13, 4054.

THANASSOULIS, J. 2014. Bank pay caps, bank risk, and macroprudential regulation. Journal of Banking \& Finance, 48, 139-151.

THIRIPALRAJU, M. \& ACHARYA, R. H. 2010. Modeling Volatility for the Indian Stock Market. IUP Journal of Applied Economics, 9, 79-105. 
TONZER, L. 2015. Cross-border interbank networks, banking risk and contagion. Journal of Financial Stability, 18, 19-32.

UPPER, C. 2011. Simulation methods to assess the danger of contagion in interbank markets. Journal of Financial Stability, 7, 111-125.

VALENCIA, F. 2014. Monetary policy, bank leverage, and financial stability. Journal of Economic Dynamics and Control, 47, 20-38.

VALLASCAS, F. \& HAGENDORFF, J. 2013. CEO Bonus Compensation and Bank Default Risk: Evidence from the U.S. and Europe. Financial Markets, Institutions \& Instruments, 22, 47-89.

WAGNER, W. 2007. The liquidity of bank assets and banking stability. Journal of Banking \& Finance, 31, 121-139.

WALKER, G. A. 2012. Market and regulatory balance. Journal of Banking Regulation, 13, $1-3$.

WEBER, E. U. \& HSEE, C. 1998. Cross-Cultural Differences in Risk Perception, but CrossCultural Similarities in Attitudes Towards Perceived Risk. Management Science, 44, 1205-1217.

YAHANPATH, N. 2011. A brief review of the role of shareholder wealth maximisation and other factors contributing to the global financial crisis. Qualitative Research in Financial Markets, 3, 64-77. 


\section{Appendix A - Description of variables and sources}

\begin{tabular}{ll}
\hline Variable names & Variable definition \\
\hline Risk Proxies & $\begin{array}{l}\text { ROA volatility is defined as the standard deviation of the ratio of gross pre-tax profit (including loan loss } \\
\text { provisions) to total assets over five years, that is, ROA Volatility at time } t \text { is estimated using the ROA } \\
\text { values during } t-4 \text { to } t \text {. To deal with extreme values, we have logarithmically transformed ROA volatility } \\
\text { (data from Bloomberg). }\end{array}$ \\
& $\begin{array}{l}\text { Z-score measures the distance from insolvency in standard deviations. It is defined as the Return on } \\
\text { Assets (ROA) ratio plus the Capital Asset Ratio (CAR) divided by the standard deviation of ROA, on a } \\
\text { Z-score }\end{array}$ \\
$\begin{array}{l}\text { five-year rolling window basis. To deal with extreme values, we have log transformed z-score. Higher z- } \\
\text { score values imply lower probability of insolvency, so to facilitate exposition we have multiplied the log } \\
\text { transformed z-score values by minus 1 (data from Bloomberg). }\end{array}$ \\
$\begin{array}{l}\text { Loan Loss Provisions is the annual ratio of the loan loss provisions to loans, a measure of the credit } \\
\text { quality of the loans granted by a specific bank. To deal with extreme values, we have log transformed } \\
\text { this variable (data from Bloomberg). }\end{array}$
\end{tabular}

\section{Country Cultural Variables}

Individualism

Individualism is measured based on survey responses to whether 'incomes should be made more equal or that there should be more incentives for individual effort. Consistent with Ahern et al. (2015) we track the responses to the following survey question: "How would you place your views on this scale? 1 means you completely agree with the statement on the left; 10 means you agree completely with the statement on the right; and if your views fall somewhere in between, you can choose any number in between:

Incomes should be made more equal - We need larger income differences as incentives for individual effort."

Higher values indicate more individualism. We re-scale the variable so that it takes values between zero and one (data from World Values Survey).

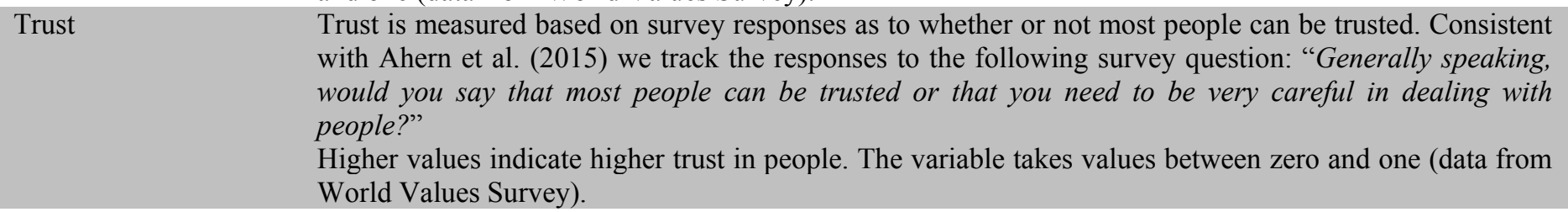

Hierarchy Hierarchy is measured based on survey responses as to whether or not one follows instructions at work or has to be convinced first. Consistent with Ahern et al. (2015) we track the responses to the following survey question: "People have different ideas about following instructions at work. Some say that one should follow one's superior's instructions even when one does not fully agree with them. Others say that one should follow one's superior's instructions only when one is convinced that they are right. With which of these two options do you agree? 1. Should follow instructions; 2. Must be convinced first."

Higher values indicate higher hierarchy, i.e., that people are happy to follow instructions without being convinced first. The variable takes values between zero and one (data from World Values Survey).

\section{Country Variables}

GDP per capita

GDP growth volatility

Legal origin

Domestic credit \%

GDP

Bank Financial Variables

Bank size

Bank leverage

Bank net interest

marginal revenue

Interest activity

Other Controls

Domestic CEO

Listed
GDP per capita is measured as the logarithm of a country's GDP per capita (data from World Bank Database).

GDP growth volatility is the standard deviation of the year on year GDP growth of a country over five years (data from World Bank Database).

Legal origin is an indicator variable, taking the values 1, 2, 3 or 4 representing the four legal origins, that is, English law (1), French law (2), German law (3), Scandinavian law (4) (data from La Porta 1998).

Domestic Credit is the percentage ratio of the domestic credit provided by the financial sector to GDP (data from World Bank Database).

Bank size is the logarithmic transformation of the bank's total assets (data from Bloomberg).

Bank leverage is the ratio Total Equity / Total Assets (data from Bloomberg).

Bank net interest marginal revenue is the ratio (Interest Income - Interest expense) / Interest income (data from Bloomberg).

Interest activity is the ratio Interest income / Total operating income and measures the percentage of the bank's income originating from traditional banking activities (data from Bloomberg).

A binary variable taking the value of one if the CEO is a national of the bank's headquartering country, zero otherwise (data from Boardex). A binary variable taking the value of one if the bank is listed on any stock exchange, zero otherwise (data 


\begin{tabular}{ll}
\hline Variable names & Variable definition \\
\hline Restrict Index & $\begin{array}{l}\text { from Bloomberg). } \\
\text { Restrict index takes values from } 3 \text { to } 12 \text { and measures the degree to which banks are permitted to engage } \\
\text { in non-lending activities, that is, securities, insurance, and real estate activities (Barth et al., 2013). }\end{array}$ \\
Degree of transparency & $\begin{array}{l}\text { The degree of transparency index takes values from } 0 \text { to } 6 \text { and measures the transparency in banks' } \\
\text { financial statements (Barth et al., 2013). }\end{array}$ \\
Cash flow index & $\begin{array}{l}\text { The cash flow index measures the cash flow rights of the largest shareholder of the bank (Laeven and } \\
\text { Levine, 2009). }\end{array}$ \\
Managerial ownership & $\begin{array}{l}\text { Managerial ownership measures the cash flow rights of senior managers (Laeven and Levine, 2009). } \\
\text { Thformation sharing }\end{array}$ \\
$\begin{array}{l}\text { The Information sharing index measures the depth of information sharing among creditors and takes } \\
\text { values from 0 to 6 (Djankov et al., 2007). }\end{array}$ \\
index
\end{tabular}


Figure 1 - Average Culture Values by country

Figure 1 presents the average (time-series and cross-sectional) scores for each cultural value, namely, individualism, trust, and hierarchy, by country.

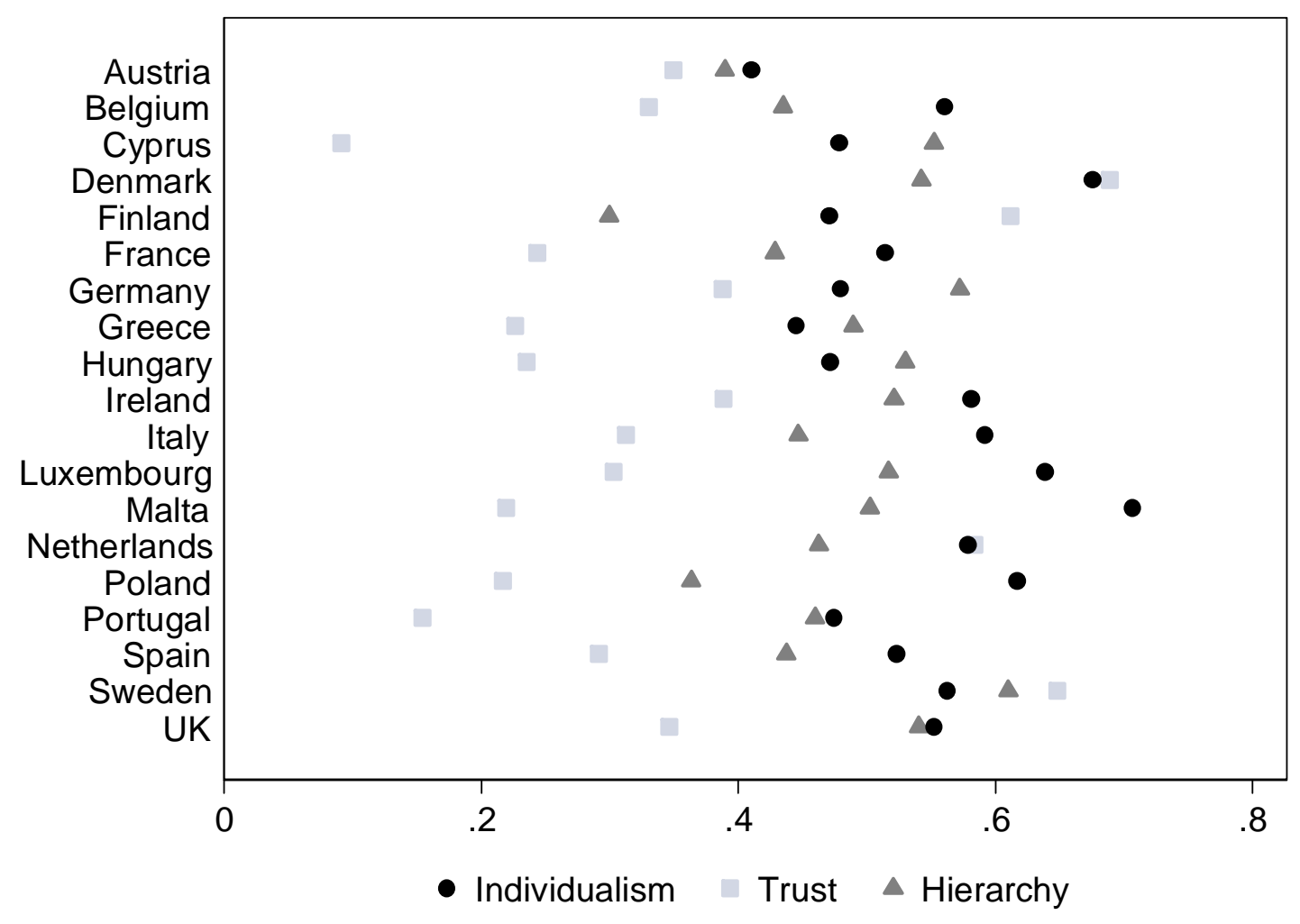




\section{Figure 2 - Risk and Return on Assets by Country}

Figure 2 plots the average (time-series and cross-sectional) Return on Assets (ROA) as well as the ROA volatility for our sample banks in each country.

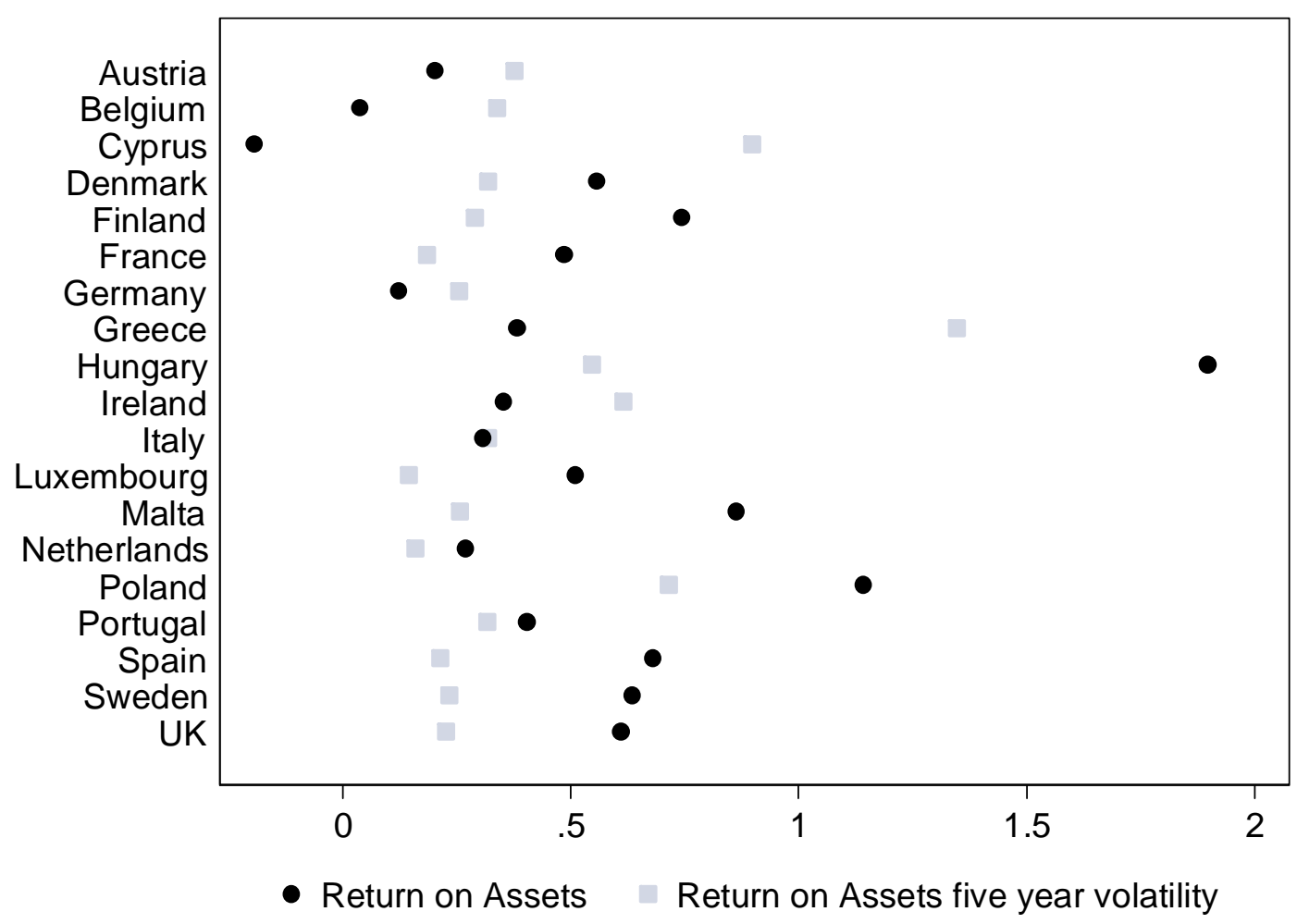




\section{Table 1 - Descriptive Statistics}

This table reports the mean, standard deviation, median, $25^{\text {th }}$ percentile, and $75^{\text {th }}$ percentile for every variable included in our models. Appendix A provides the definition for each variable.

\begin{tabular}{|c|c|c|c|c|c|}
\hline Variable / Statistic & Mean & Std & Median & $25^{\text {th }}$ & $75^{\text {th }}$ \\
\hline \multicolumn{6}{|l|}{ Dependent Variables } \\
\hline ROA volatility & 0.38 & 0.60 & 0.23 & 0.12 & 0.41 \\
\hline ROA volatility (log) & -1.50 & 1.00 & -1.52 & -2.16 & -0.89 \\
\hline Z-score & 4.50 & 10.25 & 2.68 & 0.76 & 5.37 \\
\hline Z-score (log) & -0.99 & 1.22 & -1.20 & -1.77 & -0.26 \\
\hline Loan Loss Provisions & 0.08 & 0.09 & 0.05 & 0.03 & 0.09 \\
\hline Loan Loss Provisions (log) & -2.63 & 1.16 & -2.58 & -3.22 & -1.94 \\
\hline \multicolumn{6}{|l|}{ Cultural Variables } \\
\hline Individualism & 0.53 & 0.08 & 0.55 & 0.48 & 0.59 \\
\hline Trust & 0.35 & 0.14 & 0.32 & 0.27 & 0.42 \\
\hline Hierarchy & 0.49 & 0.08 & 0.47 & 0.43 & 0.55 \\
\hline \multicolumn{6}{|l|}{ Country Variables } \\
\hline GDP per capita (log) & 10.33 & 0.49 & 10.44 & 10.07 & 10.67 \\
\hline GDP growth volatility & 1.93 & 1.10 & 1.68 & 1.06 & 2.74 \\
\hline Domestic Credit \% GDP & 1.38 & 0.49 & 1.36 & 1.07 & 1.62 \\
\hline Legal Origin & 2.41 & 0.83 & 2.00 & 2.00 & 3.00 \\
\hline \multicolumn{6}{|l|}{ Bank Financial Variables } \\
\hline Bank Size (log) & 11.24 & 1.63 & 11.20 & 10.26 & 12.39 \\
\hline Bank Leverage & 0.06 & 0.03 & 0.05 & 0.04 & 0.07 \\
\hline Net Interest Marginal Revenue & 0.45 & 0.21 & 0.45 & 0.29 & 0.60 \\
\hline Interest Activity ratio & 7.03 & 8.80 & 5.02 & 3.00 & 9.30 \\
\hline \multicolumn{6}{|l|}{ Other Controls } \\
\hline Domestic CEO & 0.93 & 0.25 & 1.00 & 1.00 & 1.00 \\
\hline Listed & 0.77 & 0.42 & 1.00 & 1.00 & 1.00 \\
\hline Restrict Index & 6.00 & 1.63 & 6.00 & 5.00 & 7.00 \\
\hline Financial Statement Transparency Index & 5.00 & 0.76 & 5.00 & 5.00 & 6.00 \\
\hline Cash Flow Rights & 0.23 & 0.13 & 0.18 & 0.13 & 0.32 \\
\hline Managerial Ownership & 0.01 & 0.03 & 0.00 & 0.00 & 0.00 \\
\hline Information Sharing depth amongst creditors Index & 5.11 & 0.95 & 5.25 & 4.50 & 6.00 \\
\hline Capital Stringency Index & 4.49 & 1.70 & 5.00 & 3.00 & 6.00 \\
\hline
\end{tabular}




\section{Table 2 - Main regression results}

This table reports multilevel (hierarchical) regression results. The dependent variable is the logarithmic transformation of the ROA volatility. Column 1 covers the period from 1995 to 2014, column 2 covers the nonfinancial crisis period from 1995 to 2006 and 2011 to 2014 and column 3 covers the financial crisis period from 2007 to 2010. The sample includes all banks in our dataset, both global and domestic. All variables are defined in Appendix A. ${ }^{*}, * *$ and $* * *$ denote significance at the $10 \%, 5 \%$ and $1 \%$ levels respectively. Numbers in brackets report the t-statistic.

\begin{tabular}{|c|c|c|c|}
\hline Variable & $\begin{array}{c}\text { All years } \\
(1)\end{array}$ & $\begin{array}{c}\text { Non-financial crisis } \\
(2)\end{array}$ & $\begin{array}{c}\text { Financial crisis } \\
\text { (3) }\end{array}$ \\
\hline \multicolumn{4}{|l|}{ Cultural Variables } \\
\hline Individualism & $\begin{array}{c}0.338 * * * \\
(4.72)\end{array}$ & $\begin{array}{c}0.397 * * * \\
(4.70)\end{array}$ & $\begin{array}{l}0.162 \\
(1.34)\end{array}$ \\
\hline Trust & $\begin{array}{c}-0.530 * * * \\
(-7.76)\end{array}$ & $\begin{array}{c}-0.705 * * * \\
(-8.64)\end{array}$ & $\begin{array}{l}-0.061 \\
(-0.50)\end{array}$ \\
\hline Hierarchy & $\begin{array}{c}0.199 * * * \\
(2.86)\end{array}$ & $\begin{array}{c}0.300 * * * \\
(3.52)\end{array}$ & $\begin{array}{l}0.059 \\
(0.54)\end{array}$ \\
\hline \multicolumn{4}{|l|}{ Country Variables } \\
\hline GDP per capita & $\begin{array}{c}0.090 * * * \\
(4.41)\end{array}$ & $\begin{array}{c}0.137 * * * \\
(5.56)\end{array}$ & $\begin{array}{c}-0.114 * * \\
(2.51)\end{array}$ \\
\hline GDP growth volatility & $\begin{array}{c}-0.051 * * * \\
(-7.43)\end{array}$ & $\begin{array}{c}-0.058 * * * \\
(-7.36)\end{array}$ & $\begin{array}{l}0.005 \\
(0.30)\end{array}$ \\
\hline Domestic Credit \% GDP & $\begin{array}{c}-0.050^{* * *} \\
(-3.61)\end{array}$ & $\begin{array}{c}-0.039 * * \\
(-2.20)\end{array}$ & $\begin{array}{l}0.022 \\
(0.91)\end{array}$ \\
\hline Legal Origin & $\begin{array}{c}0.026^{* *} \\
(2.52)\end{array}$ & $\begin{array}{c}0.041 * * * \\
(3.28)\end{array}$ & $\begin{array}{l}-0.021 \\
(-1.11)\end{array}$ \\
\hline \multicolumn{4}{|l|}{ Bank Financial Variables } \\
\hline Bank Size & $\begin{array}{c}-0.016^{* * *} \\
(-3.82)\end{array}$ & $\begin{array}{c}-0.01 * * \\
(-2.13)\end{array}$ & $\begin{array}{c}-0.03 * * * \\
(-4.96)\end{array}$ \\
\hline Bank Leverage & $\begin{array}{l}-0.050 \\
(-0.22)\end{array}$ & $\begin{array}{l}0.228 \\
(0.85)\end{array}$ & $\begin{array}{c}-0.39 \\
(-1.06)\end{array}$ \\
\hline Net Interest Marginal Revenue & $\begin{array}{c}-0.094 * * * \\
(-3.30)\end{array}$ & $\begin{array}{c}-0.094 * * * \\
(-2.76)\end{array}$ & $\begin{array}{c}-0.097 * * \\
(-2.31)\end{array}$ \\
\hline Interest Activity & $\begin{array}{c}-0.004 * * * \\
(-6.85)\end{array}$ & $\begin{array}{c}-0.006^{* * * *} \\
(-6.97)\end{array}$ & $\begin{array}{c}-0.002 * * * \\
(-3.13)\end{array}$ \\
\hline \multicolumn{4}{|l|}{ Other Controls } \\
\hline Domestic CEO & $\begin{array}{c}-0.032 * * \\
(-1.98)\end{array}$ & $\begin{array}{l}-0.016 \\
(-0.78)\end{array}$ & $\begin{array}{l}-0.031 \\
(-1.40)\end{array}$ \\
\hline Listed & $\begin{array}{c}0.036^{* *} \\
(2.53)\end{array}$ & $\begin{array}{c}0.035^{* *} \\
(1.99)\end{array}$ & $\begin{array}{c}0.035^{*} \\
(1.80)\end{array}$ \\
\hline Restrict Index & $\begin{array}{l}0.003 \\
(0.82)\end{array}$ & $\begin{array}{c}0.012 * * * \\
(2.71)\end{array}$ & $\begin{array}{c}0.014 * * \\
(1.99)\end{array}$ \\
\hline Financial Statement Transparency & $\begin{array}{c}-0.018^{* *} \\
(-2.48)\end{array}$ & $\begin{array}{l}-0.012 \\
(-1.34)\end{array}$ & $\begin{array}{c}-0.101 * * * \\
(-5.92)\end{array}$ \\
\hline Capital Stringency Index & $\begin{array}{c}0.000 \\
(-0.09)\end{array}$ & $\begin{array}{l}0.004 \\
(1.08)\end{array}$ & $\begin{array}{c}-0.025 * * * \\
(-3.03)\end{array}$ \\
\hline Cash Flow Rights & $\begin{array}{c}-0.109^{*} \\
(-1.88)\end{array}$ & $\begin{array}{l}-0.073 \\
(-1.03)\end{array}$ & $\begin{array}{l}-0.111 \\
(-1.10)\end{array}$ \\
\hline Managerial Ownership & $\begin{array}{c}-0.919 * * * \\
(-5.78)\end{array}$ & $\begin{array}{c}-0.793 * * * \\
(-4.20)\end{array}$ & $\begin{array}{c}-1.353 * * * \\
(-4.71)\end{array}$ \\
\hline Information Sharing & $\begin{array}{l}0.065^{* * * *} \\
(8.39)\end{array}$ & $\begin{array}{l}0.065 * * * \\
(7.13)\end{array}$ & $\begin{array}{l}0.056^{* * * *} \\
(3.76)\end{array}$ \\
\hline Year FEs & YES & YES & YES \\
\hline Adjusted $\mathrm{R}^{2}$ & 0.334 & 0.365 & 0.434 \\
\hline Number of obs. & 1232 & 936 & 296 \\
\hline
\end{tabular}




\section{Table 3 - Domestic banks}

This table reports multilevel (hierarchical) regression results. The dependent variable is the logarithmic transformation of the ROA volatility. Column 1 covers the period from 1995 to 2014, column 2 covers the nonfinancial crisis period from 1995 to 2006 and 2011 to 2014 and column 3 covers the financial crisis period from 2007 to 2010. The sample includes only domestic banks. All models include the control variables used in our main specification but we don't report their coefficients for brevity. All variables are defined in Appendix A. *, $* *$ and $* * *$ denote significance at the $10 \%, 5 \%$ and $1 \%$ levels respectively. Numbers in brackets report the $\mathrm{t}$ statistic.

\begin{tabular}{|c|c|c|c|}
\hline Variable & $\begin{array}{l}\text { All years } \\
\text { (1) }\end{array}$ & $\begin{array}{l}\text { Non-financial crisis } \\
\text { (2) }\end{array}$ & $\begin{array}{c}\text { Financial crisis } \\
\text { (3) }\end{array}$ \\
\hline \multicolumn{4}{|l|}{ Cultural Variables } \\
\hline Individualism & $\begin{array}{c}0.344 * * * \\
(4.32)\end{array}$ & $\begin{array}{c}0.425 * * * \\
(4.53)\end{array}$ & $\begin{array}{l}0.154 \\
(1.16)\end{array}$ \\
\hline Trust & $\begin{array}{c}-0.528 * * * \\
(-6.86)\end{array}$ & $\begin{array}{c}-0.733 * * * \\
(-7.84)\end{array}$ & $\begin{array}{l}-0.092 \\
(-0.68)\end{array}$ \\
\hline Hierarchy & $\begin{array}{c}0.243 * * * \\
(3.10)\end{array}$ & $\begin{array}{c}0.346 * * * \\
(3.54)\end{array}$ & $\begin{array}{l}0.109 \\
(0.92)\end{array}$ \\
\hline Country Variables & YES & YES & YES \\
\hline Bank Financial Variables & YES & YES & YES \\
\hline Other Controls & YES & YES & YES \\
\hline Year FEs & YES & YES & YES \\
\hline Adjusted $\mathrm{R}^{2}$ & 0.335 & 0.366 & 0.437 \\
\hline Number of obs. & 1040 & 754 & 256 \\
\hline
\end{tabular}




\section{Table 4 - Global banks}

This table reports multilevel (hierarchical) regression results. The dependent variable is logarithmic transformation of the ROA volatility. Column 1 covers the period from 1995 to 2014 and column 2 covers the non-financial crisis period from 1995 to 2006 and 2011 to 2014. The results for the financial crisis period (20072010) are not reported because of the inadequate sample size (40 observations). The sample includes only global banks. All models include the control variables used in our main specification but we don't report their coefficients for brevity. All variables are defined in Appendix A. *, ** and *** denote significance at the 10\%, $5 \%$ and $1 \%$ levels respectively. Numbers in brackets report the t-statistic.

\begin{tabular}{lcc}
\hline Variable & $\begin{array}{c}\text { All years } \\
(1)\end{array}$ & $\begin{array}{c}\text { Non-financial crisis } \\
(2)\end{array}$ \\
\hline Cultural Variables & & \\
Individualism & 0.222 & 0.231 \\
& $(0.96)$ & $(0.76)$ \\
Trust & 0.257 & 0.199 \\
& $(1.50)$ & $(1.02)$ \\
Hierarchy & 0.227 & 0.561 \\
& $(0.63)$ & $(1.17)$ \\
Country Variables & YES & YES \\
Bank Financial Variables & YES & YES \\
Other Controls & YES & YES \\
Year FEs & YES & YES \\
Adjusted R & 0.344 & 0.374 \\
Number of obs. & 192 & 152 \\
\hline
\end{tabular}




\section{Table 5 - Alternative risk proxies}

This table reports multilevel (hierarchical) regression results. The dependent variable in Panel A (Panel B) is the logarithmic transformation of the z-score (the logarithmic transformation of the loan loss provisions). Column 1 covers the period from 1995 to 2014, column 2 covers the non-financial crisis period from 1995 to 2006 and 2011 to 2014 and column 3 covers the financial crisis period from 2007 to 2010. The sample includes all banks in our dataset, both global and domestic. All models include the control variables used in our main specification but we don't report their coefficients for brevity. All variables are defined in Appendix A. *,** and *** denote significance at the $10 \%, 5 \%$ and $1 \%$ levels respectively. Numbers in brackets report the t-statistic.

Panel A: Z-score

\begin{tabular}{|c|c|c|c|}
\hline Variable & $\begin{array}{l}\text { All years } \\
\text { (1) }\end{array}$ & $\begin{array}{l}\text { Non-financial crisis } \\
\text { (2) }\end{array}$ & $\begin{array}{c}\text { Financial crisis } \\
\text { (3) }\end{array}$ \\
\hline \multicolumn{4}{|l|}{ Cultural Variables } \\
\hline Individualism & $\begin{array}{c}0.023 * * * \\
(4.73)\end{array}$ & $\begin{array}{l}0.024 * * * \\
(4.16)\end{array}$ & $\begin{array}{l}0.010 \\
(1.02)\end{array}$ \\
\hline Trust & $-0.028 * * *$ & $-0.036 * * *$ & 0.010 \\
\hline Hierarchy & $\begin{array}{c}(-5.94) \\
0.017 * * * \\
(3.27)\end{array}$ & $\begin{array}{c}(-6.33) \\
0.021 * * * \\
(3.30)\end{array}$ & $\begin{array}{l}(1.01) \\
-0.002 \\
(-0.21)\end{array}$ \\
\hline Country Variables & YES & YES & YES \\
\hline Bank Financial Variables & YES & YES & YES \\
\hline Other Controls & YES & YES & YES \\
\hline Year FEs & YES & YES & YES \\
\hline Adjusted $\mathrm{R}^{2}$ & 0.358 & 0.347 & 0.429 \\
\hline Number of obs. & 1164 & 882 & 282 \\
\hline \multicolumn{4}{|l|}{ Panel B: Loan Loss Provisions } \\
\hline Variable & $\begin{array}{c}\text { All years } \\
(1)\end{array}$ & $\begin{array}{c}\text { Non-financial crisis } \\
\text { (2) }\end{array}$ & $\begin{array}{c}\text { Financial crisis } \\
\text { (3) }\end{array}$ \\
\hline \multicolumn{4}{|l|}{ Cultural Variables } \\
\hline \multirow[t]{2}{*}{ Individualism } & $1.498 * * *$ & $3.538 * * *$ & -1.214 \\
\hline & $\begin{array}{c}(2.50) \\
-2.568 * * *\end{array}$ & $\begin{array}{c}(5.06) \\
-4.123 * * *\end{array}$ & $\begin{array}{l}-1.15 \\
-1.170\end{array}$ \\
\hline Hierarchy & $\begin{array}{c}(-3.94) \\
0.652 \\
(1.00)\end{array}$ & $\begin{array}{c}(-5.61) \\
1.636^{* *} \\
(2.30)\end{array}$ & $\begin{array}{c}-0.96 \\
0.070 * \\
(0.06)\end{array}$ \\
\hline Country Variables & YES & YES & YES \\
\hline Bank Financial Variables & YES & YES & YES \\
\hline Other Controls & YES & YES & YES \\
\hline Year FEs & YES & YES & YES \\
\hline Adjusted $\mathrm{R}^{2}$ & 0.481 & 0.519 & 0.433 \\
\hline Number of obs. & 1345 & 1000 & 345 \\
\hline
\end{tabular}




\section{Table 6 - Instrumental variables regression}

We use instrumental variables regression with 2SLS which generates heteroskedasticity-robust standard errors. The $2^{\text {nd }}$ stage dependent variable is the logarithmic transformation of the ROA volatility. Panel A reports the selection process for the Instrumental Variables (IVs) we use for the endogenous regressors approximating national culture. National cultural values are instrumented by the fractionalization variables Ethnicity, Language and Religion (Alesina et al., 2003) as well as Geography (Kwok and Solomon, 2006). All $2^{\text {nd }}$ stage models include the control variables used in our main specification but we don't report their coefficients for brevity. All these variables are defined in Appendix A. * $* *$ and $* * *$ denote significance at the $10 \%, 5 \%$ and $1 \%$ levels respectively. The number in brackets is the t-statistic.

\begin{tabular}{lccc}
\multicolumn{3}{l}{ Panel A: Instrument Selection for Individualism, Trust, and Hierarchy } \\
\hline Instruments & Individualism & Trust & Hierarchy \\
\hline Ethnicity & $-0.1627^{* * *}$ & $-0.0681^{* *}$ & $0.2183^{* * *}$ \\
& $(-6.24)$ & $(-2.31)$ & $(8.41)$ \\
Religion & $-0.2151 * * *$ & $-0.1108^{* *}$ & $0.2123^{* * *}$ \\
& $(-12.80)$ & $(-6.06)$ & $(12.70)$ \\
Geography & $-0.0672^{* * *}$ & $-0.0506 * * *$ & $-0.0147 * * *$ \\
& $(-11.86)$ & $(-7.85)$ & $(-2.61)$ \\
Language & $0.1617^{* * *}$ & $0.1788^{* * *}$ & $-0.2667 * * *$ \\
& $(8.12)$ & $(7.93)$ & $(-13.45)$ \\
F-test & $42.38^{* * *}$ & $151.13^{* * *}$ & $33.08^{* * *}$ \\
\hline
\end{tabular}

Panel B: Stage 2 regression results

\begin{tabular}{lc}
\hline Individualism & $1.7397 * * *$ \\
Trust & $(8.00)$ \\
& $-1.4644 * * *$ \\
Hierarchy & $(-4.18)$ \\
& $0.6701 * * *$ \\
Controls & $(3.37)$ \\
Year FEs & YES \\
Observations & YES \\
Anderson under-identification test (F test) & 1232 \\
& 52.55 \\
Test of weak instruments (Hansen's J) & p-value $=0.000$ \\
& 2.291 \\
\end{tabular}

